\title{
Dinosaurs, Hospital Ecosystems, and the Future of Family Medicine
}

\section{Cherie Glazner, MD, MSPH}

Fort Collins Family Medicine Residency Program, Poudre Valley Health System, Fort Collins, Colorado
AC Annals Journal Club selection; see inside back cover or http://www. annfammed.org/AJC/.

Conflicts of interest: none reported.

\section{CORRESPONDING AUTHOR}

Cherie Glazner, MD, MSPH 1025 Pennock Place Fort Collins, CO 80524 glazch@pvhs.org

\begin{abstract}
The continued presence of the family physician within hospital systems is key to family medicine remaining an attractive, viable specialty in the ever-evolving world of medicine. One physician muses about her place in this complex ecosystem and believes that family physicians lose their voice and thus risk their own extinction when they opt out of hospital practice.
\end{abstract}

Ann Fam Med 2008;6:38-369. DOI: 10.1370/afm.863.

I sat in a meeting recently debating the medical staff structure of a new hospital going up just down the road. The new hospital's focus would be invasive cardiology and trauma, but all recognized that patients with any diagnosis would be admitted through its shiny new doors. The discussion centered on whether there should be primary care departments in this sister facility. The general internist of the group looked over at me, the lone family doctor among the various specialists, and with a pained expression whispered that he was a dinosaur in a changed hospital ecosystem that no longer seemed to have a place for him. He wondered whether there remained a role for primary care physicians in an increasingly complex medical system dominated by hospitalists, specialists, and invasive procedures.

The internist's statement forced me to stop and ask myself whether I, too, was obsolete but either too foolish to see it or too bullheaded to admit it. Few family physicians here continued to deliver babies, and although a few more took care of newborns, very few of us continued to walk the halls of the hospital at all hours of day and night to care for adults. The question hung heavy and caused me to pause, for I loved the intensity of the hospital and being present for my patients during those sacred moments of illness, birth, and death.

As the current chief of the family medicine department in the existing hospital, I was facing a rapidly changing environment. While plans for the new specialty hospital were moving forward, a hospitalist service, comprised of newly graduated internists willing to work 12-hour shifts, had started in our hospital. More than one-half of the 100 or so family physicians on staff had turned over their hospitalized patients to these newcomers in the past year. These family physicians confessed that although initially they felt guilty about handing their patients over to strangers, their own lives had improved so immensely that they would never consider going back to the old ways.

Resolution to my uncertainty came to me most unexpectedly. The next day my mom called s $_{i}$ has taking my 85 -year old grandmother, 6 days after receiving a stent in her left main coronary artery, to the hospital. I met them in the strange familiarity of a distant emergency department. The cardiologist, wizened and gray headed, had no explanation for her 
sodium of $120 \mathrm{mEq} / \mathrm{L}$, her bigeminy, and her low blood pressure. My grandmother, who had raised 4 children on a subsistence dry-land farm with no water or plumbing, explained in her tired and timid voice that the problem was too much medication, but to no avail. The nephrologist would see her in the morning. She wasn't having a heart attack. Her stent was fine. Dismissed.

The next morning, feeling fatigued, defeated, and fearful of death, my grandmother confided that no one appeared to be in charge. First one cardiologist, then another, had come in without answers. The nephrologist had not yet been in, but she was restricted to $1,000 \mathrm{~mL}$ of fluid for the day. She wanted to know why no one had spoken to her family physician. He knew that her sodium bottomed out on hydrochlorothiazide, which the cardiologists, unaware of her history, had started 6 days ago. Her family doctor knew she could not tolerate a blood pressure of less than 120/70 mm $\mathrm{Hg}$, but the cardiologist's opinion was otherwise. Her family physician knew her passion lay in her rose beds and perennial gardens now that water was freely abundant to her. He understood that for my grandmother to feel too weak to stand up and walk her gardens was a type of death.

With fiercely determined tearful eyes, my mother took my arm and marched me next door to the ambulatory clinics, along the same path I had walked as a small child visiting my own family physician, full of dreams of one day becoming a doctor. My mother visibly relaxed when her family doctor sat down across from her, her trust sure in this physician who has cared for her and my grandmother over many years, through many stories. He no longer sees his patients in the hospital, he explained, with the pained look on his face that I had seen so often these past few years. But he agreed to call the specialists and confer on my grandmother's case.

It was enough for my grandmother. She felt safer and death was farther away. The nephrologist agreed to advocate for fewer medications and a higher blood pressure. She returned home after 2 days of medication-induced illness to her brilliant roses, bright sunflowers, and crimson hollyhocks. I returned to work with my answer - the involvement of the family physician within the hospital benefits patients and specialists.

It is not the "basket of services"1 that creates a place for me in the ever-evolving ecosystem of hightech hospitals. It is not an electronic health record that gives my place value. Drs Green and Phillips presented a question in the Future of Family Medicine Project, "What should the family physician's role be in the future, and how can it be realized?"2 I can answer the first part unequivocally and without hesitation: my role is to be my patient's advocate, a keeper of their stories, an audible voice in the cacophony of medicine, a translator of terms, a moderator of specialists, an advocate for disease prevention, and a master of primary care medical practice. I cannot have a voice if I am not present.

The question is not so much which services to offer to whom as much as it is how to make the work of the family physician financially and emotionally sustainable, thus supporting continued involvement in the hospital setting. I choose to see my patients in the hospital, usher new babies into this world, sit by patients on ventilators run by intensivists, and manage diabetes for those undergoing the latest technological invasion. Perhaps I am bullheaded, but I fear that the voluntary disappearance of the family physician from the community hospital adversely affects not only the health of the patient but also the health and wellbeing of family medicine.

I understand why many primary care physicians choose other paths. Time and money are cruel taskmasters. We desire to live fully and joyfully outside our medical practices, devoting time and attention to our loved ones. The day of the solo practitioner being all things to all people at all times might be over, but disappearing from hospital practice may be the wrong answer. I believe that family physicians' conscious withdrawal from the halls of the hospital sabotages the future of family medicine and the role of the family doctor within health care. Our absence renders us voiceless. We create the very extinction that we fear when we are missing from the bedside of our patients.

We must explore deeply and debate openly the question of how to realize our role in the broader health care system, and we must creatively find those interfaces that sustain not only the individual family doctor, but also the specialty of family medicine, ${ }^{2}$ for the answer may be the difference between a viable future and extinction.

To read or post commentaries in response to this article, see it online at http://www.annfammed.org/cgi/content/full/6/4/368.

Key words: Family practice; continuity of patient care; hospitalists; medical errors; primary health care

Submitted January 28, 2007; submitted, revised, March 6, 2008; accepted March 24, 2008.

\section{References}

1. Martin JC, Avant RF, Bowman MA, et al. The future of family medicine: a collaborative project of the family medicine community. Ann Fam Med. 2004;2(Suppl 1):S3-S32.

2. Green LA, Phillips RL, Jr. The family physician workforce: quality, not quantity. Am Fam Physician. 2005;71(12):2248, 2253. 